\title{
Святой человек и практика исцелений в Восточном Средиземноморье в начале IV - середине V вв.
}

\author{
А.А. Данилов \\ Национальный исследовательский Нижегородский государственный университет \\ им. Н.И. Лобачевского, \\ Россия, 603950, г. Нижний Новгород, пр. Гагарина, 23 \\ E-mail: an.danilov@icloud.com
}

\begin{abstract}
Аннотация. Работа посвящена изучению практики исцеления святых в эпоху Поздней античности. Работа построена на исследовании агиографических источников и в некоторой степени восполняет имеющуюся в современной историографии лакуну, связанную с изучением практики чудесного исцеления на христианском Востоке в период поздней античности. Позднеантичный период с его особенным отношением к вопросам болезни и ее социальному значению практически ускользает из поля зрения современных историков. В данной работе акцент ставится не столько на медицинские аспекты исцелений, сколько на социальные аспекты практики святых, что придает работе определенную новизну и актуальность. Автор показывает, что святые осуществляют важные социальные функции и предоставляют механизм существования целой группе людей, выброшенной из социума, - тяжело больным, калекам и умирающим.
\end{abstract}

Ключевые слова: Поздняя античность, святость, исцеления, социальные практики.

Для цитирования: Данилов А.А. 2021. Святой человек и практика исцелений в Восточном Средиземноморье в начале IV - середине V вв. Via in tempore. История. Политология, 48 (1): 25-35. DOI: 10.52575/2687-0967-2021-48-1-25-35.

\section{The holy man and the practice of healing in the Eastern Mediterranean at the beginning of 4 th - mid 5 th cent. A. D.}

\author{
Andrey A. Danilov \\ National Research Lobachevsky State University of Nizhny Novgorod, \\ 23 Gagarin Ave., Nizhni Novgorod, 603950, Russia \\ E-mail: an.danilov@icloud.com
}

\begin{abstract}
Annotation. The work is devoted to the study of the practice of healing saints in the Late antiquity. The work is based on the study of hagiographic sources and to some extent fills the gap in modern historiography associated with the study of the practice of miraculous healing in the Christian East during the Late antiquity. The late antique period, with its special attitude to the issues of disease and its social significance, practically escapes the field of view of modern historians. This work focuses not so much on the medical aspects of healing, but on the social aspects of the practice of saints, which gives the work a certain novelty and relevance. The author shows that saints perform important social functions and provide a mechanism for the existence of a whole group of people who are thrown out of society - the seriously ill, the crippled, and the dying. The Eastern Mediterranean is of great importance for the study of transitional historical processes in the period of Late Antiquity.
\end{abstract}

Keywords: Late antiquity, Holiness, healing, social practices. 
For citation: Danilov A.A. 2021. The holy man and the practice of healing in the Eastern Mediterranean at the beginning of 4 th - mid 5th cent. A. D. Via in tempore. History and political science, 48 (1): 25-35 (in Russian). DOI: 10.52575/2687-0967-2021-48-1-25-35.

\section{Введение}

Традиционно проблематика болезни и здоровья человека в исторической науке связывается с историей медицины [Шлюмбом, Хагнер, Сироткина, 2008, с. 8-40], мы же попытаемся рассмотреть эти вопросы с точки зрения истории позднеантичного христианства, концентрируя свое внимание на деятельности восточных святых.

Христианский Восток (Восточное Средиземноморье) периода Поздней античности - это место формирования христианского мировоззрения, а также скрупулезного поиска решения острых социальных проблем своего времени, среди которых болезни и положение больных в обществе, являлась одной из самых главных ${ }^{1}$.

В ранней Византии медицинская практика профессиональных врачей, в особенности в сельской местности и для бедных слоев населения, была либо полностью недоступна, либо очень ограничена [McNeill, 1998]. Отсутствие врачей или их неспособность вылечить людей породили большое количество больных и искалеченных, которые были вынуждены искать решения своих проблем иными способами. Одним из таких путей стало обращение за помощью к святому человеку.

Практика исцелений святыми всегда находилась под пристальным вниманием ученых. Взгляд на нее менялся с течением времени: если изначально она рассматривалась как сюжет мифологии и народных суеверий [Freudenthal, 1931] и находилась в поле исследований сравнительного религиоведения, языкознания и антропологии, то впоследствии, к 60-м годам XX в., на исцеления обратили свое внимание историки как на культурный феномен, существовавший в повседневной жизни европейцев в эпоху Средневековья. Практика чудесного исцеления обратила на себя особое внимание при изучении эпидемий, охвативших Европу в XIV в. ${ }^{2}$ На современном этапе эта практика изучается с точки зрения восприятия болезни, ее значения для формирования культуры, воображения и ментальности средневекового человека [Sigal, 1985].

Однако в контексте этих исследований абсолютно незаслуженно практически без внимания осталась практика исцелений, сформировавшаяся на христианском Востоке в период Поздней античности ${ }^{3}$. Это кажется особенно странным в связи с тем, что это время является начальным этапом формирования христианского представления не только о болезни и ее лечении, но и о святости как таковой, и должно представлять особый интерес для ученых.

\section{Методы исследования}

В работе был использован сравнительно-исторический метод относительно материалов различных источников. Историко-биографический метод применялся при изучении отдельных персоналий. Контент-анализ был использован при анализе содержания письменных источников по теме.

\footnotetext{
${ }^{1}$ Более подробно о проблеме болезней и эпидемий см.: [McNeill, 1998].

${ }^{2}$ Например, см.: [Biraben, 1975; Biraben, 1976].

${ }^{3}$ Исключением может служить работа Питера Брауна, который вскользь касается этой темы: [Brown, 2008, p. 781-810; Brown, 1981, p. 80-101]. Современная российская наука делает лишь первые попытки в продвижении в данном направлении: [Яцык, 2018; Арнаутова, 2004].
} 


\section{Результаты исследования}

После окончания эры гонений на христиан, когда постепенное исчезновение мучеников снова поставило вопрос о том, кого можно считать «свидетелем веры» [Festugière, 1949, p. 98-99], идеал христианской жизни постепенно стал ассоциироваться с аскетическими подвигами [Delehaye, 1927, p. 122-123]. В этом контексте развитие монашества на территории Сирии, Палестины и Египта в начале IV в. становится центральным местом деятельности святых.

Для историка все события этого этапа в истории христианства представляют особую ценность в связи с тем, что они были описаны очевидцами: Феодоритом Кирским ${ }^{4}$ и Палладием Еленопольским ${ }^{5}$.

Феодорит Кирский родился в 393 г. в состоятельной семье в Антиохии ${ }^{6}$. Его родители, по разным сведениям, имели или греческое, или сирийское происхождение и принадлежали к «верхушке» городской элиты. Феодорит получил блестящее для своего времени образование: обучался у лучших преподавателей в одном из главных центров мировой культуры, помимо греческого говорил на сирийском и еврейском языках, превосходно разбирался в античной философии.

С самого раннего возраста Феодорит проникся восхищением монашеской жизнью и сначала стал чтецом при храме в Антиохии, а после ушел в монастырь недалеко от Апамеи [Сидоров, 1996а, с. 7]. В 423 г. Феодорит стал епископом небольшого городка Кирр, расположенного недалеко от Антиохии [Сидоров, 1996а, с. 9]. В этом статусе Феодорит проводил активную церковную и гражданскую благотворительную деятельность [Сидоров, 1996а, с. 9].

Практику исцеления Феодорит описывает как необходимую работу, которая выполняется не по собственному желанию, а в связи с личным долгом. Так, описывая историю подвижника Иулиана, Феодорит подчеркивает, что святой посчитал необходимым приступить к исцелению, несмотря на собственное плохое состояние [Canivet, LeroyMolinghen, 1979, p. 238]. Святой здесь предстает как обычный человек, который тоже болеет. Однако, когда поднимается вопрос о помощи людям, святой, имея возможность отказать, осознает свою ответственность и принимается за работу.

Феодорит подчеркивает, что сами святые болеют точно так же, как и все остальные люди. Однако отличает их от простых людей способ исцеления. Если простой человек лечится с помощью врачей и лекарств, то святой лечится только молитвой (Theodor. Cyrrh. HR. XXII. Thalassius et Limnaius, 4). Заболевание святого, способное привести к его смерти, означало для людей возможность прикоснуться к нему, взять частичку его останков с верой в их целительные качества. При этом даже если святой еще был жив, это не мешало людям отхватить кусок его одежды или волос. Такое поведение Феодорит объясняет евангельскими сюжетами. В истории о подвижнике Иулиане святой исцелил нищего, даже не подозревая об этом. Такое «случайное» исцеление произошло благодаря прикосновению нищего к краю его плаща [Canivet, Leroy-Molinghen, 1979, p. 238-240].

Описывая примеры исцеления, Феодорит показывает читателю добросовестно исполняющего свои обязанности работника. Так, например, когда св. Юлиана попросили явиться в дом местного чиновника для его исцеления, святой немедленно отправился на место и сразу же вылечил больного [Canivet, Leroy-Molinghen, 1979, p. 238-240].

Исполнение святым его «обязанностей» целителя в широком смысле слова, затрагивало не только лечение людей, но и животных, при этом техника лечения ничем не отличается от лечения человека. Так, например, св. Фалелей исцелял домашний скот, чем

\footnotetext{
${ }^{4}$ Оригинал: [Migne, 1864, p. 1279-1498]. Русский перевод: [Сидоров, 1996b].

${ }^{5}$ Оригинал: [Butler, 1904]. Русский перевод: [еп. Евсевий Орлинский, 2011].

${ }^{6}$ Исследованию жизни Феодорита посвящены: [Azema, 1990, p. 418-435; Глубоковский, 1890a; Глубоковский, 1890b].
} 
заслужил особое уважение местного населения. В истории про св. Афраата Феодорит рассказывает, как подвижник вылечил коня императора Валента, по просьбе пришедшего к нему конюшего (Theodor. Cyrrh. HR. VIII. Aphrahat, 11). Стоит отметить в этой истории две вещи: первое, что за помощью к Афраату пришли уже после обращения к ветеринарам, которые не смогли вылечить коня, чем автор как бы подчеркивает их некомпетентность по сравнению со святым, и второе, что пришедший к Афраату конюший был человеком «благочестивым и крепким верой», что связывает способность подвижника помочь просителю с необходимостью наличия у просителя христианской веры. Здесь, по нашему мнению, ключевым является не то, что конюший верит в возможность помощи, а скорее то, что его христианская жизнь является знаком отличия, из-за которого святой соглашается оказать помощь. Лечение коня является скорее необычным явлением в практике этого святого, и только потому, что его попросил это сделать носитель определённых качеств - «благочестивой и крепкой веры», святой выполнил просьбу.

Точно такую же идею об исцелении только верующих людей указывает Феодорит в истории о собственной матери, которая была излечена св. Петром от болезни глаза (Theodor. Cyrrh. HR. IX. Petrus, 5-6). В этой истории Феодорит показывает, что его мать не соответствовала обликом тому человеку, которому святой готов был помогать. Ее внешний вид вызвал у святого возмущение, однако это не послужило для него поводом для категорического отказа в помощи. Петр убедил мать Феодорита изменить свой внутренний и внешний облик, как условие оказания помощи, и как только женщина выполнила требуемое, вылечил ее. Более того, после излечения Петр указал ей на необходимость соблюдения правил для последующей жизни в качестве профилактики от болезни. В дальнейшем, когда мать Феодорита исполнила все слова святого, она начала пользоваться его расположением и приводить к нему различных больных, которые в той или иной степени были связаны с ней: это мог быть повар или земледелец, трудившийся у нее. Их всех Петр исцеляет от одержимости уже не из-за них, а из-за женщины. По ее просьбе он изгоняет бесов из ее работников и спасает ее саму от смерти при родах (Theodor. Cyrrh. HR. IX. Petrus, 7-14).

Вообще Феодорит отмечает, что спектр болезней, которые святой может исцелить, неограничен: это касается всех физических болезней, в том числе бесплодия (Theodor. Cyrrh. HR. XI. Romanus, 4), но, кроме того, и болезней душевных. Так, в истории про Македония Феодорит описывает интересное заболевание некой женщины, которая страдает от излишнего переедания, при этом сам автор сомневается, является ли это болезнью души или тела. В любом случае после вмешательства святого по просьбе супруга больной болезнь отступает (Theodor. Cyrrh. HR. XIII. Macedonius, 9). Вопрос о том, почему женщина испытывает недуг, является предметом размышлений, и когда святой исцеляет женщину, эта проблема отпадает сама собой.

Феодорит ясно отождествляет беснование с душевным заболеванием или с безумием, указывая на то, что человек, одержимый бесом, именно болен, как и болезнями тела, разница только в лечении. Болезни души или беснования святой исцеляет изгнанием. При этом меры, необходимые для изгнания, порой требовали нестандартных решений. Одно такое изгнание, совершенное св. Македонием, потребовало целого разбирательства в гражданском суде, где сам святой выступал в качестве судьи, а бес - в качестве обвиняемого (Theodor. Cyrrh. HR. XIII. Macedonius, 10-12). Данный сюжет показывает не только власть святого, но и отношение к его методам со стороны окружающих. Для них святой непререкаемый авторитет в вопросах избавления от конкретной напасти, его эффективность в этом деле не подвергается сомнению ни со стороны обывателя, ни со стороны представителя власти. Его степень воздействия соответствуют требуемым ожиданиям, которые святой выполняет очень точно.

Точность и эффективность лечения святого подчеркивается Феодоритом путем сравнения с обычными врачами, которые оказываются неспособными помочь человеку. 
Святой же намного эффективнее справляется со сложными заболеваниями, в особенности душевными. Так, после безрезультатного лечения у простых врачей супруг заболевшей женщины обращается к святому, который исцеляет еe (Theodor. Cyrrh. HR. XIII. Macedonius, 13).

Вместе с тем лечение у обычных врачей, отмечает Феодорит, является обязательным средством, отказываться от которого нельзя. Так, Македоний попрекает мать Феодорита за то, что она не следует советам врачей по приему лекарств (Theodor. Cyrrh. HR. XIII. Macedonius, 17-18).

Феодорит показывает святых в виде той конечной инстанции, которая способна помочь в тяжелых случаях, когда существующая медицина либо не может помочь, либо ее просто нет. Святые лечат людей как в массовом порядке, так и в единичном, по личной просьбе и даже по случайному стечению обстоятельств. При этом сами святые также подвержены всем видам заболеваний, как и все остальные люди: они также болеют, страдают и умирают. Однако при этом святые абсолютно точно осмысляют и понимают причину собственных заболеваний, и, самое главное, они знают, что нужно сделать, чтобы вылечиться. Поэтому они либо легко выздоравливают, производя самолечение, либо благополучно умирают, осмысляя свою смерть как логичный конец их деятельности. Для простых же людей тяжелое заболевание, в особенности душевное, вызывает страх и непонимание того, что им делать, что и побуждает их обращаться сначала к врачам, помощь которых, как показывает Феодорит, остается неудовлетворительной, и уже после - к святому, видя в нем последнюю надежду на исцеление.

Второй автор - Палладий Еленопольский, родился в Галатии в 363 или 364 г. [Lowther Clarck, 1918, p. 16]. В 386 г. он оставил мирскую жизнь и отправился в Палестину, где принял монашество. До этого момента известно довольно мало из его жизни. В своем произведении он указывает, что у него были, по крайней мере, один брат и одна сестра, которые также были монахами [Lowther Clarck, 1918, p. 16]. О родителях Палладия известно только то, что его отец прожил долгую жизнь, а мать скончалась, когда он ушел в монастырь [Lowther Clarck, 1918, p. 18].

В период с 386 по 388 г., во время нахождения на Елеонской горе, Палладий имел тесные контакты с находящимися здесь великими христианскими подвижниками - Меланией Старшей и Руфином Аквилейским, оказавшими на него глубокое влияние [Lowther Clarck, 1918, p. 18]. Впоследствии, в 412-413 гг., Палладий вернулся на Елеонскую гору, побывав в Египетской пустыне, а также Риме и Вифинии, где был рукоположен в епископы города Еленополь [Lowther Clarck, 1918, p. 18]. Роковое значение для Палладия сыграло его поддержка Иоанна Златоуста, из-за которой он был сослан в Фиваиду [Lowther Clarck, 1918, p. 18]. Однако к 413 г. Палладий вновь появился на Елеонской горе. Здесь он и написал свой главный труд - «Лавсаик», в котором описал историю жизни и подвижничества египетских монахов. Временной промежуток этого произведения захватывает период с конца IV до начала V вв., а территориально - Северный Египет и Палестину. Так же, как и в случае с Феодоритом Кирским, Палладий был лично знаком со многими описываемыми им подвижниками.

В «Лавсаике» в изобилии присутствуют примеры исцелений, совершаемые святыми. Важное значение Палладий приписывает причинам возникновения у святого дара целительства, что всегда связывается с определенным образом жизни, включающим в себя нахождение вне социума, исключительное пищевое поведение, выраженное в крайне редком и специфическом питании и постоянном совершении молитв. Именно в связи с этими качествами в истории о подвижнике Оре Палладий описывает механизм достижения способности исцелять людей (Pallad. Laus. IX. Orus). Варианты исполнения подобного образа жизни весьма разнообразны и могут меняться в зависимости от личного выбора святого. Подвижник Павел прошел целое испытание, если не сказать издевательство, со стороны 
св. Антония Великого, дабы доказать свое право стать монахом и впоследствии целителем (Pallad. Laus. XXII. Paulus Simplex).

Во всех случаях человек, который выполнил все условия, получал дар исцелять болезни, что было связано, прежде всего, со способностью объяснить природу любого заболевания. Болезнь и ее развитие было непосредственно связано с каким-либо грехом, совершение которого непременно вызывало недуг. Св. Макарий Египетский, например, связал заболевание проказой с грехом сребролюбия (Pallad. Laus. XVII. Macarius Aegyptius). Макарий Александрийский указывает на тяжкое заболевание, изъевшее голову местного пресвитера, как на следствие блудного греха (Pallad. Laus. XVIII. Macarius Alexandrinus).

В связи с тем, что количество грехов не ограничено, количество болезней, описанных Палладием, также очень велико. Непосредственная связь заболевания с грехом дает возможность святым лечить практически любую болезнь. Палладий приводит описание исцеления от значительного количества болезней. Так, например, св. Аммун излечил бешенство (Pallad. Laus. XI. Ammonius), Макарий Египетский вылечил рак (Pallad. Laus. XVII. Macarius Aegyptius), Иоанн Ликопольский излечил болезнь глаза жены местного чиновника, а также лихорадку одного из монахов, живших в его монастыре (Pallad. Laus. XXXV. Ioannes Lycopolitanus). Подвижник Аммун вылечил пастуха, упавшего в обморок и разбившего себе голову от падения (бешенство (Pallad. Laus. XI. Ammonius). Св. Иоанн вылечил шедшего к нему на исцеление хромого человека (Pallad. Laus. XXXV. Ioannes Lycopolitanus).

Палладий указывает, что святые подвижники имеют различную специализацию в исцелениях. Так, Антоний Великий не может изгнать беса у пришедшего к нему одержимого юноши в связи с тем, что он «не получил еще власти над сим главнымм чином демонов». Однако этим даром обладает другой подвижник - Павел, который потом и изгнал беса (Pallad. Laus. XXII. Paulus Simplex). Палладий подчеркивает в этой истории, что Павел достиг большего мастерства именно в вопросе изгнания бесов и имеет лучшие способности в исцелении одержимых. Кроме того, у Палладия описано несколько специализаций, в которых одни святые преуспевают в большей степени, чем другие. Так, описывая историю двух братьев Исайи и Паисия, он показывает, что один из них прославился тем, что мог лечить людей, успокаивая их души (Pallad. Laus. XIV. Paesius et Isaias). Св. Стефан имел точно такую же способность излечивать любую печаль путем разговора с людьми так, что «всякий, у кого была какая-нибудь печаль, побеседовав с ним, отходил от него без печали» (Pallad. Laus. XXIV. Stephanus). Кто-то из святых специализировался на исцелении с помощью лекарственных средств (Pallad. Laus. XXXV. Ioannes Lycopolitanus), а некто Евлогий вообще посвятил всю свою жизнь попечительству одного увечного инвалида, у которого не было ни рук, ни ног (Pallad. Laus. XXI. Eulogius), что можно назвать интересной формой соединения заботы о здоровье, пропитании и существовании неспособного на это человека.

Предоставление практики исцеления у святых подвижников показано у Палладия как весьма распространенный механизм. Массовость обращения к святым показана в истории Макария Египетского, ученик которого «был у него слугою и всегда находился при нем для приходивших врачеваться» (Pallad. Laus. XVII. Macarius Aegyptius).

Палладий описывает весь процесс лечения человека у святого от начала его заболевания до полного исцеления с указанием причин заболевания, клинической картины течения болезни, выбора «лечащего врача» - обычного светского или святого, сам процесс исцеления и применения лекарственных средств, а также меры профилактики заболевания. Весь этот процесс описан и в истории Макария Египетского, который вылечил женщину от того, что всем вокруг она казалась лошадью (Pallad. Laus. XVII. Macarius Aegyptius).

Первый этап, а именно описание причины заболевания, представлен Палладием как следствие безуспешных попыток одного египтянина соблазнить замужнюю женщину. После неудачи мужчина отправился к колдуну, который сделал так, что женщина стала ви- 
деться всем вокруг лошадью. Прежде всего, стоит отметить, что женщина не превратилась в лошадь, а только стала видеться таковой. Иными словами, женщина не заболела сама, а лишь стала причиной галлюцинаций у окружающих, что объяснялось святым нечистотой взгляда у обычных людей. Святой сразу же увидел женщину, а не лошадь.

Второй этап, а именно описание клинической картины заболевания, показан Палладием в появлении у женщины таких недугов, которые мешают ей нормально жить: это полное изменение образа жизни и, самое страшное, изменение пищевого поведения женщина не могла есть.

Третий этап, связанный с выбором лечащего врача, отражен в реакции мужа на увиденное. Супруг при этом точно осознает, что перед ним его жена, которой требуется лечение. В связи с этим он сначала обращается к пресвитерам своего селения, которые вообще не увидели проблемы, после чего муж решает отвести супругу в пустыню к святому.

Четвертый этап описывается Палладием как исцеление Макарием этой женщины путем обливания святой водой и принудительном кормлении, которое и становится причиной полного выздоровления.

Последний этап, описывающий профилактику заболевания и предупреждение рецидива, выражен в наставлении святого этой женщине. Макарий говорит, что причиной, по которой с ней вообще могло случиться подобное, связано с тем, что она давно не причащалась, и только постоянное совершение этого таинства позволит ей избежать заболевания в последующем.

Описанная схема действий больного человека и его родственников в случаях заболевания применима практически ко всем историям исцеления святыми, с той лишь разницей, что некоторые этапы либо пропущены автором, либо намеренно скрыты в связи с обстоятельствами и характером заболевания. В особенности, специфическое лечение требовалось в сложных случаях психических расстройств, которые отождествлялись с одержимостью. Порой для изгнания бесов требовалось совершить необычные манипуляции, однако в любом случае действия святого всегда были направлены на исцеление больного.

В случаях, когда заболевание было незначительным и не угрожало жизни больного, лечение могло проходить без личного контакта. Для этого требовалось обратиться к святому либо самому больному, либо его родственнику, и если святой посчитает возможным, то больному прописывалось лекарственное средство - помазание елеем с определенной периодичностью, что в итоге приводило к исцелению. При этом сам святой совершал молитвы за больного, которые в сочетании с использованием елея приводили к нужному результату. Именно такой случай описан в истории об Иоанне Ликопольском (Pallad. Laus. XXXV. Ioannes Lycopolitanus). Больным здесь выступает женщина, и сложность заключается в том, что супруг этой женщины уверяет ее, что святой отказывается принимать женщин вообще. Но после настойчивых просьб супруг отправляется к святому, и тот назначает лечение на дому с использованием специальных лекарств - это помазание елеем, которое необходимо совершать три раза в день в течение трех дней. Принципы святого в ограничении общения с женщинами в данном случае не становятся помехой для исцеления, так как проходят по иному сценарию - без личного контакта.

Восприятие протекания болезни у святого кардинально отличается от заболевания обычного человека. Палладий, описывая историю св. Вениамина, указывает на его пренебрежительное отношение к собственной смертельной болезни (Pallad. Laus. XII. Beniaminus). Вениамин, даже будучи смертельно болен, продолжал исцелять людей. Жившие с ним монахи сравнивали Вениамина с Иовом, что весьма характерно отражает осмысление не только заболевания, но и его причины и последствия именно для святого человека.

Представленные в работах Палладия и Феодорита примеры чудесных исцелений содержат в себе принципиальное решение проблемы здоровья для своего времени.

Описываемые ими болезни были разными, и многие из них были либо неизлечимы, либо неизвестны врачам. Заболевший такой болезнью человек оказывался предоставлен 
сам себе. Ему оставалось либо приспосабливаться, если болезнь не смертельна, либо ждать смерти, если наоборот, либо мучить своих родственников, если болезнь душевная. Таких людей, судя по количеству обращений, было очень много, и специфика их существования была большой проблемой не только для них самих, но и для окружающих их людей. Феодорит довольно ясно описал это в истории болезни женщины, страдающей чрезмерным объедением. Ее родственники стали бить тревогу потому, что она истощила их запасы пропитания. Таким образом, болезнь этой женщины поставила ее саму и ее родственников в такую ситуацию, когда они вынуждены были искать решения проблемы, не имея возможности отмахнуться от нее.

Именно в таком состоянии они встречают святого - в состоянии неопределенности и страха перед предстоящей жизнью. Страх движет людьми, которым не помогло лечение у обычных врачей. Жизнь таких людей почти всегда сопряжена с проживанием в нищете, с постоянным физическим или душевным страданием, неспособностью удовлетворить элементарные человеческие потребности. В этом контексте история об исцелении - это история о помощи неизлечимо больным людям.

Оба автора описывают достаточное количество болезней, давая им конкретные определения, показывая тем самым, что в их мире существовало несколько видов неизлечимых заболеваний. У нищего отказали ноги, сошедшая с ума женщина не могла ни есть, ни пить, несчастный пресвитер, заболевший раком, просто валялся на земле и ждал смерти.

Феодорит и Палладий подчеркивают, что святой - это последняя инстанция, куда обращаются люди, когда уже ничего не может помочь. Без их помощи неизлечимо больные будут влачить жалкое существование. Еще вчера здоровый человек, который сегодня заболевает, понимает, что впереди у него - перспектива превратиться в нищего на улице. И он не знает, как этого избежать. Единственное, что ему остается, - это искать тех, кто уже сталкивался с подобной проблемой, чтобы понять, как действовать в подобной ситуации. Именно об этом говорит Феодорит в истории своей матери, которой подруга посоветовала обратиться к святому, ведь он уже излечивал такие болезни.

Палладий описывает принципиальную схему действий человека в случае, когда его проблема выходит за рамки существующей медицины. Он подробнейшим образом рассказывает, как действует святой после обращения к нему. Феодорит дополняет, что святой это дисциплинированный ответственный исполнитель, который ставит проблемы своих пациентов выше своих собственных. Наконец, оба автора сходятся на том, что каждый святой подвержен всем тем же болезням, что и остальные, и приводят достаточное количество примеров. Таким образом, святой предстает тем, кто понял, осмыслил и вылечил заболевание в самом себе. Он первым из всех прошел этот путь от заболевания до момента исцеления. И он, святой, предлагает каждому пройти его путь.

\section{Заключение}

Таким образом, главное, что дает исцеление, - это объяснение, почему человек болеет вообще. Оба изученных нами ранневизантийских автора подчеркивают, что этого объяснения существующая медицина не дает. Люди при этом, видя эффективность их метода лечения и неспособность существующей медицины помочь им, перенимают взгляд святых на причины своего заболевания и осмысляют несчастье, приключившееся с ними, в тех категориях, которые предлагают им святые.

Таким образом, святые в узком смысле осуществляют не только лечение тела, но и массовую психотерапию. В широком смысле святые предоставляют механизм существования целой группе людей, выброшенной из социума - тяжелобольным, калекам и умирающим. 


\section{Список сокращений}

Pallad. Laus. - Palladius, Historia Lausiaca

Theodor. Cyrrh. HR. - Theodoretus Cyrrhus, Historia Religiosa

\section{Список литературы}

1. Арнаутова Ю.Е. 2004. Колдуны и святые: Антропология болезни в средние века. СПб., Алетейя, 398.

2. Глубоковский Н.Н. 1890. Блаженный Феодорит, епископ Киррский. Его жизнь и литературная деятельность. Т. 1. М., 349.

3. Глубоковский Н.Н. 1890. Блаженный Феодорит, епископ Киррский. Его жизнь и литературная деятельность. Т. 2. М., 510.

4. Сидоров А.И. 1996а. Блаженный Феодорит Кирский - архипастырь, монах, богослов. Его значение в истории древнехристианской Церкви и православного богословия. М., Паломник: $7-45$.

5. Сидоров А.И. (изд.). 1996b. Феодорит Кирский. История Боголюбцев. М., Паломник, 448.

6. Терновский С.А. 1899. Очерки из церковно-исторической географии. Области восточных патриархов Православной Церкви до IX века. Вып.1. Казань, 190.

7. Филиппов И.С. 2019. О святости, корректности и горизонтах науки. Заметки о сборнике статей «Европа святых: социальные, политические и культурные аспекты святости в средние века». СПб., Алетейя, 323 с. В: Средние века. Т. 80. 3: 192-209.

8. Шлюмбом Ю., Хагнер М., Сироткина И. 2008. Введение. История медицины: актуальные тенденции и перспективы. В: Болезнь и здоровье: новые подходы к истории медицины. СПб., Алетейя: 8-40.

9. Яцык С.А. (изд.). 2018. Европа святых. Социальные, политические и культурные аспекты святости в Средние века. СПб., Алетейя, 324.

10. Azema Y. 1990. Théodoret de Cyr. In: Dictionnaire de spiritualité, fasc. XCVI-XCVIII. Paris: 418-435.

11. Bartlett R. 2013. Why Can the Dead Do Such Great Things? Saints and Worshippers from the Martyrs to the Reformation. Oxford, 815.

12. Biraben J.N. 1975. Les hommes et la peste en France et dans les pays europoens et rnediterrancens. T. I. Paris, 452.

13. Biraben J.N. 1976. Les hommes et la peste en France et dans les pays europoens et rnediterrancens. T. II. Paris, 416.

14. Brown P. 1971. The rise and function of the Holy man in late Antiquity. In: Journal of Roman Studies. Vol. 61: 80-101.

15. Brown P. 2008. Holy Man. In: The Cambridge Ancient History. Late Antiquity: Empire and Successors, A. D. 425-600. vol. 14. Cambridge, UP: 781-810.

16. Butler C. (ed.). 1904. Palladius. Historia Lausiaca. Cambridge, University press, 398.

17. Cameron A. 1999. On defining the holy man. In: The Cult of Saints in Late Antiquity and the Middle Ages. Essays on the Contribution of Peter Brown. Oxford: 27-43.

18. Canivet P., Leroy-Molinghen A. (ed.). 1977. Théodoret de Cyr. Histoire des moines de Syrie. Sources Chrétiennes 234. vol. 1. Paris, 513.

19. Canivet P., Leroy-Molinghen A. (ed.). 1979. Théodoret de Cyr. Histoire des moines de Syrie. Sources Chrétiennes 257. vol. 2. Paris, 469.

20. Chadwick H. 1981. Pachomios and the Idea of Sanctity. In: The Byzantine Saint. London: $25-31$.

21. Clarck E. 2008. From Patristics to Early Christian Studies. In: The Oxford Handbook of Early Christian Studies. New York: 7-42.

22. Dagron G. 1968. La vie ancienne de saint Marcel l'Acemetes. In: Analecta Bollandiana. Vol. 85: $271-321$.

23. Delehaye H. 1927. Sanctus: essai sur le culte des saints dans l'antiquité. Subsidia hagiographica. Vol. 17, 265. 
24. Drijvers H.J.W. 1981. Hellenistic and Oriental Origins. In: The Byzantine Saint. London: $11-25$

25. Festugière A.-J. 1949. La sainteté. In: Mythes et religions.Vol. 9: 1-103 (In French).

26. Freudenthal H. 1931. Das Feuer im deutschen Glauben und Brauch Berlin; Leipzig, 32.

27. Lowther Clarck W.K. (ed.). 1918. The Lausiac History of Palladius, a Critical Edition. New York, The Macmillan Company, 245.

28. McNeill W.H. 1998. Plagues and Peoples. New York, Anchor Books; Doubleday, 340.

29. Migne J.-P. (ed.). 1864. Theodoretus Cyrensis. Historia religiosa In: Patrologia Graeca. T. LXXXII. Theodoretus, Cyrensis Episcopus. Opera Omnia: 1279-1498.

30. Patlagean E. 1968. Ancienne hagiographie byzantine et histoire sociale. In: Annales: Economies, Société, Civlisations. Vol. 23: 106-123.

31. Ryden L. 1981. The Holy Fool. In: The Byzantine Saint. London: 106-117.

32. Vauchez A. 1988. La sainteté en Occident aux demiers siècles du Moyen Age d'apres les proces de canonisation et les documents hagiographiques. Rome, 765.

33. Whitby M. 1987. Maro the Dendrite: an Anti-Social Holy Man? In: Homo Viator, Classical Essays for John Bramble. Bristol: 309-317.

\section{References}

1. Arnautova Yu.E. 2004. Kolduny i svyatye: Antropologiya bolezni v srednie veka [Sorcerers and Saints: An Anthropology of Disease in the Middle Ages]. St. Petersburg, Aletejya, 398 (in Russian).

2. Glubokovskij N.N. 1890a. Blazhennyj Feodorit, episkop Kirrskij. Ego zhizn' i li-teraturnaya deyatel'nost' [Blessed Theodorite, Bishop of Cyrrhus. His life and literary activity]. T. 1. Moscow, 349 (in Russian).

3. Glubokovskij N.N. 1890b. Blazhennyj Feodorit, episkop Kirrskij. Ego zhizn' i literaturnaya deyatel'nost' [Blessed Theodorite, Bishop of Cyrrhus. His life and literary activity]. T. 2. Moscow, 510 (in Russian).

4. Sidorov A.I. 1996a. Blazhennyj Feodorit Kirskij - arhipastyr', monah, bogoslov. Ego znachenie v istorii drevnekhristianskoj Cerkvi i pravoslavnogo bogosloviya [Blessed Theodorite of Cyrus - archpastor, monk, theologian. Its significance in the history of the ancient Christian Church and Orthodox theology]. Moscow, Palomnik: 7-45 (in Russian).

5. Sidorov A.I. (ed.). 1996b. Feodorit Kirskij. Istoriya Bogolyubcev [Theodorite of Cyrrhus. History of the God-lovers]. Moscow, Palomnik, 448 (in Russian).

6. Ternovskij C.A. 1899. Ocherki iz cerkovno-istoricheskoj geografii. Oblasti vostochnyh patriarhov Pravoslavnoj Cerkvi do IX veka [Essays from church-historical geography. Areas of the Eastern Patriarchs of the Orthodox Church until the 10th century]. Issue. 1. Kazan', 190 (in Russian).

7. Filippov I.S. 2019. O svyatosti, korrektnosti i gorizontah nauki. Zametki o sbornike statej «Evropa svyatyh: social'nye, politicheskie i kul'turnye aspekty svyato-sti v srednie veka». St. Petersburg, Aletejya, 2018. 323 s. [About holiness, correctness and horizons of science. Notes on the collection of articles «Europe of Saints: Social, Political and Cultural Aspects of Holiness in the Middle Ages». St. Petersburg, Aleteya, 2018. 323 p.]. In: Srednie veka [Middle Ages]. T. 80. 3: 192-209 (in Russian).

8. Shlyumbom Yu., Hagner M., Sirotkina I. 2008. Vvedenie. Istoriya mediciny: aktual'nye tendencii i perspektivy [Introduction. History of medicine: current trends and prospects]. In: Bolezn' i zdorov'e: novye podhody $\mathrm{k}$ istorii mediciny [Disease and Health: New Approaches to the History of Medicine]. St. Petersburg, Aletejya: 8-40 (in Russian).

9. Yacyk S.A. (ed.). 2018. Evropa svyatyh. Social'nye, politicheskie i kul'turnye aspekty svyatosti v Srednie veka [Europe of saints. Social, Political and Cultural Aspects of Holiness in the Middle Ages]. St. Petersburg, Aletejya, 324 (in Russian).

10. Azema Y. 1990. Théodoret de Cyr. In: Dictionnaire de spiritualité, fasc. XCVI-XCVIII. Paris: 418-435 (In French).

11. Bartlett R. 2013. Why Can the Dead Do Such Great Things? Saints and Worshippers from the Martyrs to the Reformation. Oxford, 815.

12. Biraben J.N. 1975. Les hommes et la peste en France et dans les pays europoens et rnediterrancens. T. I. Paris, 452 (In French).

13. Biraben J.N. 1976. Les hommes et la peste en France et dans les pays europoens et rnediterrancens. T. II. Paris, 416 (In French). 
14. Brown P. 1971. The rise and function of the Holy man in late Antiquity. In: Journal of Roman Studies. Vol. 61: 80-101.

15. Brown P. 2008. Holy Man. In: The Cambridge Ancient History. Late Antiquity: Empire and Successors, A. D. 425-600. Vol. 14. Cambridge: 781-810.

16. Butler C. (ed.). 1904. Palladius. Historia Lausiaca. Cambridge, University press, 398.

17. Cameron A. 1999. On defining the holy man. In: The Cult of Saints in Late Antiquity and the Middle Ages. Essays on the Contribution of Peter Brown. Oxford: 27-43.

18. Canivet P., Leroy-Molinghen A. (ed.). 1977. Théodoret de Cyr. Histoire des moines de Syrie. Sources Chrétiennes 234. Vol. 1. Paris, 513 (in French).

19. Canivet P., Leroy-Molinghen A. (ed.). 1979. Théodoret de Cyr. Histoire des moines de Syrie. Sources Chrétiennes 257. Vol. 2. Paris, 469 (in French).

20. Chadwick H. 1981. Pachomios and the Idea of Sanctity. In: The Byzantine Saint. London: $25-31$.

21. Clarck E. 2008. From Patristics to Early Christian Studies. In: The Oxford Handbook of Early Christian Studies. New York: 7-42.

22. Dagron G. 1968. La vie ancienne de saint Marcel l'Acemetes. In: Analecta Bollandiana. Vol. 85: 271-321 (In French).

23. Delehaye H. 1927. Sanctus: essai sur le culte des saints dans l'antiquité. Subsidia hagiographica. Vol. 17, 265 (In French).

24. Drijvers H.J.W. 1981. Hellenistic and Oriental Origins. In: The Byzantine Saint. London: $11-25$.

25. Festugière A.-J. 1949. La sainteté. In: Mythes et religions. Vol. 9: 1-103 (In French). German).

26. Freudenthal H. 1931. Das Feuer im deutschen Glauben und Brauch Berlin; Leipzig, 32 (In

27. Lowther Clarck W.K. (ed.). 1918. The Lausiac History of Palladius, a Critical Edition. New York, The Macmillan Company, 245.

28. McNeill W.H. 1998. Plagues and Peoples. New York, Anchor Books; Doubleday, 340.

29. Migne J.-P. (ed.). 1864. Theodoretus Cyrensis. Historia religiosa In: Patrologia Graeca. T. LXXXII. Theodoretus, Cyrensis Episcopus. Opera Omnia: 1279-1498.

30. Patlagean E. 1968. Ancienne hagiographie byzantine et histoire sociale. In: Annales: Economies, Société, Civlisations. Vol. 23: 106-123 (in French).

31. Ryden L. 1981. The Holy Fool. In: The Byzantine Saint. London: 106-117.

32. Vauchez A. 1988. La sainteté en Occident aux demiers siècles du Moyen Age d'apres les proces de canonisation et les documents hagiographiques. Rome, 765 (in French).

33. Whitby M. 1987. Maro the Dendrite: an Anti-Social Holy Man? In: Homo Viator, Classical Essays for John Bramble. Bristol: 309-317.

\section{ИНФОРМАЦИЯ ОБ АВТОРЕ}

Данилов Андрей Александрович, магистрант кафедры средневековых цивилизаций Национального исследовательского Нижегородского государственного университета им. Н.И. Лобачевского, Россия

\section{INFORMATION ABOUT THE AUTHOR}

Andrey A. Danilov, Master's student of the Department of Medieval Civilizations of the National Research Lobachevsky State University of Nizhny Novgorod, Russia 